\title{
Pelatihan Penggunaan Aplikasi Dewan Masjid Indoensia (DMI) Untuk Pengelolaan Produk dan Kegiatan Masjid Kota Semarang
}

\author{
Training of Dewan Masjid Indonesia (DMI) Application for Management \\ Products and Activity in Semarang Mosque
}

\author{
Galuh Wilujeng Saraswati ${ }^{1}$, Muhammad Syaifur Rohman ${ }^{2}$, Nurul Anisa Sri Winarsih ${ }^{3}$ \\ ${ }_{1,2,3}$ Fakultas Ilmu Komputer, Universitas Dian Nuswantoro \\ E-mail: ${ }^{1}$ galuhwilujengs@dsn.dinus.ac.id, ${ }^{2}$ syaifur@dsn.dinus.ac.id, ${ }^{3}$ nurulanisasw@dinus.dsn.ac.id
}

\begin{abstract}
Abstrak
Saat ini peranan teknologi dibidang telekomunikasi digunakan oleh organisasi sebagai media pendukung untuk mempermudah para anggotanya mencari informasi dari suatu organisasi yang diikuti. Perpaduan Sistem Informasi dan teknologi GPS yang ada dalam smartphone ini membantu suatu organsisasi dalam melakukan Marketing Communication, sehingga para anggtota yang tegabung dalam sebuah organisasi dapat menawarkan produk/jasa yang mereka miliki ke anggota yang lain. Selain itu dalam mengembangkan potensi wisata dan ekonomi potensial masyarakat perlu adanya dukungan yang baik dari segi sarana prasarana, organisasi dan pemasaran untuk mengatur semua kegiatan sehingga semua jadwal dan agenda dapat terstruktur dengan baik. Oleh karena itu Pengurus Daerah Dewan Masjid Indonesia (PD DMI) Kota Semarang ingin membuat sebuah aplikasi berbasis android yang mewadahi seluruh kegiatan pengelolaan produk jamaah dan kegiatan masjid di Kota Semarang. Aplikasi ini bertujuan untuk mengelola seluruh aktivitas pengurus, takmir dan jamaah sehingga semua kegiatan dan informasi dapat di akses secara mudah tanpa adanya batasan waktu dan tempat. Selain itu kegiatan pengabdian ini bertujuan untuk mendukung perekonomian masyarakat sekitar masjid dan membagi informasi kegiatan rutin masjid.
\end{abstract}

Kata kunci: GPS, Marketing Communication, Aplikasi Android, DMI

\begin{abstract}
Currently the role of technology in the field of telecommunications is used by organizations as supporting media to make it easier for members to find information from an organization that is being followed. The combination of Information Systems and GPS technology that is in this smartphone helps an organization in conducting Marketing Communication, so that members who are members of an organization can offer their products / services to other members. In addition, in developing the tourism potential and economic potential of the community, there needs to be good support in terms of infrastructure, organization and marketing to organize all activities so that all schedules and agendas can be well structured. Therefore, the Regional Administrators of the Indonesian Mosque Council (PD DMI) Semarang City want to make an Android-based application that houses all the activities of the pilgrimage product management and mosque activities in the city of Semarang. This application aims to manage all management activities, takmir and pilgrims so that all activities and information can be accessed easily without any time and place restrictions. In addition this dedication activity aims to support the economy of the community around the mosque and share information on routine mosque activities
\end{abstract}

Keywords: GPSs, Marketing Comminucation, Android Aplication, DMI 


\section{PENDAHULUAN}

Kemajuan Teknologi Informasi dan komunikasi memicu tumbuhnya komunikasi digital bebasis Internet of Things (IoT). Kondisi ini mendukug berkembangnya perangkat smartphone yang memiliki kemmapuan kerja komputer tetapi dalam bentuk minimalis [1]. Salah satu produk smartphone yang banyak digunkan saat ini adalah smartphone berbasis android [2]. Teknologi smartphone android banyak diminati karena memiliki bebrapa teknologi yang canggih salah satunya adalah sistem Informasi organisasi dalam bentuk aplikasi android dan Global Postioning System (GPS) yang di tanamkan pada perangkat smartphone untuk memberikan informasi lokasi suatu tempat.

Saat ini banyak organisasi yang memanfaatkan teknologi sabagai media pendukung untuk mempermudah para anggotanya mencari informasi dari suatu organisasi yang diikutinya [3]. Perpaduan Sistem Informasi dan teknologi GPS ini membantu suatu organsisasi dalam melakukan Marketing Communication, sehingga para penjual jasa ataupun para pembeli akan datang mengunjungi tempat yang sudah ditunjukan oleh GPS tersebut. Selain itu dalam mengembangkan potensi wisata dan perekonomian potensial masyarakat perlu adanya dukungan yang baik dari segi sarana prasarana, organisasi dan pemasaran untuk mengatur semua kegiatan sehingga semua jadwal dapat terstruktur dengan baik [4].

Kota Semarang merupakan ibukota Jawa Tengah yang memiliki 1042 masjid yang tersebar di 16 Kecamatan. Banyaknya jumlah masjid yang ada di kota Semarang ini membuat Pemerintah kota Semarang kesulitan untuk memanajemen kegiatan, kondisi lingkungan masjid dan potensi masjid tersebut sehingga diperlukanya sebuah forum sebagai wadah atau media komunikasi digital melalui asuhan Dewan Masjid Indonesia (DMI). Organisasi ini memiliki tujuan untuk mewujudkan fungsi masjid sebagai pusat ibadah, pengembangan masyarakat dan persatuan umat. Berdasarkan tujuan tersebut Dewan Masjid Indonesia (DMI) Kota Semarang memiliki rencana kegiatan tahun 2019 untuk mebentuk Forum Discussion Group (FDG) mengembangkan potensi masjid Kota Semarang. Kegiatan ini bertujuan uantuk mengetahui potensi masjid di sekitar Kota Semarang meliputi kesehatan jamaah dan kebersihan lingkungan, kondisi ekonomi serta sarana prasarana. Tata kelola yang ada pada DMI Kota Semarang memiliki banyak kekurangan dimulai dari sistem pengelolaan masjid, fasilitas diskusi atau forum para takmir masjid se-Kota Semarang dan kurangnya manajemen kegiatan rutin untuk mengembangkan potensi DMI Kota Semarang.

Untuk mendukung kegiatan ini, DMI Kota Semarang menggunakan sistem informasi berbasis web dan android untuk memetakan letak masjid, pengelolaan produk jamaah, kegiatan jamaah masjid, waktu sholat dan data-data masjid. Seluruh kegiatan ini dihubungkan menjadi satu aplikasi yang dapat di akses oleh masyarakat. Tujuan dari pembuatan penelitian ini adalah untuk mempelajari dan menganalisis masalah dalam mengatur seluruh kegiatan untuk masjid di Kota Semarang, dan kemudian merancang aplikasi mobile untuk Dewan Masjid Indonesia Kota Semarang dalam memanajemen seluruh kegiatan dan potensi masjid di Kota Semarang.

Berdasarkan pemaparan dan analisis masalah diatas, PD DMI Kota Semarang memiliki permasalahan dalam pembekalan keterampilan dalam pengoperasikan teknologi. Oleh karena itu, PD DMI dan para Takmir masjid ini perlu mendapatkan pembekalan pengetahuan pengoperasian aplikasi DMI Kota Semarang sebagai penunjang dalam bidang operasional aktivitas dan administrasi kegiatan DMI di Kota Semarang.

Pengabdian masyarakat ini dilaksanakan untuk memberikan pelatihan penggunaan aplikasi DMI berbasis Android untuk memberikan keterampilan teknologi informasi dan pengoprasian aplikasi bagi para pengurus daerah DMI Kota Semarang dan para Takmir Masjid se-kota Semarang.Tujuan dari pelatihan keterampilan penggunaan aplikasi ini, setidaknya para PD DMI Kota Semarang, Para takmir dan masyarakat Kota Semarang dapat mengoperasikan aplikasi 
yang nantinya akan membantu dalam bidang operasional aktivitas dan administrasi kegiatan DMI di Kota Semarang.

\section{METODE PELAKSANAAN}

Peserta pelatihan berjumlah 36 orang yang berasal dari takmir masing masing masjid yang ada di 16 kecamatan se-Kota Semarang. Berdasarkan analisis situasi dan permasalahan mitra yang telah disampaikan pada Forum Group Discussion (FGD), bahwa Perngurus Daerah Dewan Masjid Indoensia menginginkan adanya aplikasi berbasis Mobile yang membantu mengatur pengelolaan produk dan kegiatan masjid di Kota Semarang. Tim pengabdian kepada masyarakat terdiri dari 3 orang yang memiliki tugas masing masing sesuai dengan bidang peminatanya.

Untuk mengoperasikan aplikasi ini diperlukan smartphone bebasis android dengan OS minimal jellybean. Aplikasi ini dapat diunduh melalui aplikasi playstore dengan nama DMI Kota Semarang. Program aplikasi ini memberikan informasi berupa susunan oraganisasi Dewan Masjid Indonesia Kota Semarang, Arah Kiblat, Jadwal sholat yang di sesuaikan dengan lokasi pengguna aplikasi, menunjukan lokasi masjid terdekat, dan melihat seluruh Kegiatan Masjid. Pengguna dapat mengakses semua menu informasi yang ada dalam aplikasi tersebut secara gratis, dan dapat diakses tanpa adanya Batasan ruang dan waktu. Sebelum memulai pelatihan ini peserta (takmir masjid) diminta untuk mendaftarkan nama masjidnya, lokasi yang di kirimkan melalui share location whatsapps serta foto masjid melalui website yang sudah kami sediakan.

Target dan luaran dari pengabdian masyarakat tentang Pelatihan Penggunaan Aplikasi Dewan Masjid Indonesia (DMI) untung mengelola informasi pengelolaan produk dan informasi masjid Kota Semarang adalah sebagai berikut:

A. Target tujuan yang dicapai antara lain adalah:

1. Meningkatkan pemahaman penggunaan aplikasi DMI Kota Semarang serta manfaatnya.

2. Meningkatkan kesadaran takmir masjid dan masyarkat sekitar tentang manfaat aplikasi DMI Kota Semarang.

3. Mempermudah masyarakat dalam mencari informasi masjid dan kegiatan islami.

4. Meningkatkan perekonomian masyarakat sekitar masjid melalui promosi produk industri rumah tangga.

B. Luaran dari hasil Pengabdian Berupa:

1. Pemahamaan peserta akan manfaat aplikasi DMI Kota Semarang.

2. Penambahan data masjid, kegiatan masjid dan katalog promosi produk jamaah.

3. Publikasi Jurnal Pengabdian Masyarakat.

4. Publikasi media masa.

5. Video dokumentasi kegiatan pengabdian masyarakat yang terunggah di Youtube.

Berikut ini adalah langkah-langkah pelaksanaan Pengabdian Masyarakat ini antara lain:

1. Melakukan survey dan koordinasi dengan Pengurus Dewan Masjid Indonesia (PD DMI) Kota Semarang agar pengabidan ini berjalan dengan tertib dna lancar.

2. Memberikan penjelasan singkat kepada Pengurus Dewan Masjid Indonesia (PD DMI) Kota Semarang (PD DMI) tentang kegiatan pelatihan yang akan diselenggarakan untuk mensosialisasikan manfaat aplikasi ini kepada takmir dan masyarakat disekitar masjid.

3. Memastikan kebersediaan PD DMI Kota Semarang.

4. Menentukan waktu dan tempat pelaksanaan kegiatan pengabdian

5. Melakukan persipan sarana dan prasaraa untuk kegiatan seperti: smartphone, komputer, LCD, makanan ringan, blocknote dan pensil.

6. Melakukan pengarsipan kegiatan dan pengarsipan laporannya. 
7. Menyiapakan administrasi meliputi undangan peserta, surat menyurat, dokumentasi, daftar hadir untuk diarsip dan untuk pembuatan laporan

8. Melaksanakan kegiatan dan menyiapkan tim konsultasi bagi peserta pelatihan yang memerlukan bimbingan dalam mengoperasikan aplikasi

\section{HASIL DAN PEMBAHASAN}

Pelatihan Aplikasi DMI Kota Semarang ini terdiri dari tiga tahapan. Tahap pertama dari program kemitraan pengabidan masyarakat ini adalah melakukan survei dan koordinasi dengan PD DMI Kota Semarang untuk merencanakan agenda pengabdian masyarakat berupa pelatihan penggunaan aplikasi Dewan Masjid Indonesia Kota Semarang, penyusunan panita pengurus dan penanggung jawab. Tahap selanjutnya adalah memberikan sosialisasi kepada seluruh Takmir masjid di Kota Semarang tentang penngunaan aplikasi mobile ini terutama pada bagian kegiatan masjid dan produk jamaah. Kegiatan pelatihan ini telah dilaksanakan dan berjalan dengan lancer sesuai dengan rencara, hal ini dibuktikan dengan antusiasme peserta pelatihan terhadap aplikasi yang dihasilkan Berikut ini gambaran kebiatan pelatihan yang telah di laksanankan:
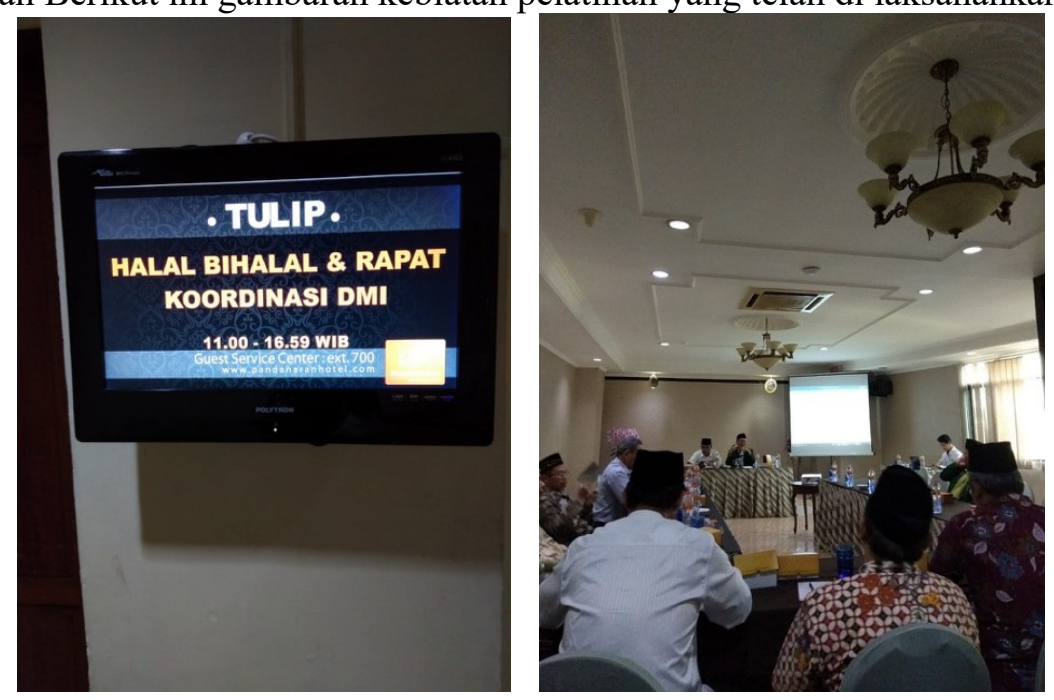

Gambar 1 Rapat Koordinasi DMI

Tahap Kedua berupa tanggapan dari solusi yang diberikan. Dalam tahapan ini perserta pelatihan ini mendapatkan pengetahuan berupa gambaran penggunaan Penggunaan aplikasi DMI Kota Semarang. Semua peserta pelatihan memberikan respon baik terhadap program pelatihan ini dan memberikan saran berupa tambahan fitur dalam aplikasi dan adanya buku panduan untuk memahami penggunaan aplikasi DMI Kota Semarang. Peserta berharap dengan adanya aplikasi ini kegiatan masjid dan pengembangan ekonomi potensial masyarakat di sekitar masjid dapat berjalan dengan baik dan lancer sehingga dengan adanya kegiatan ini dapat meningkatkan pendapatan masyarakat dan termasuk pendapatan anggaran untuk administrasi masjid demi kebermanfaatan semua makhluknya. Tahap uji coba digambarkan pada gambar dibawah ini. 


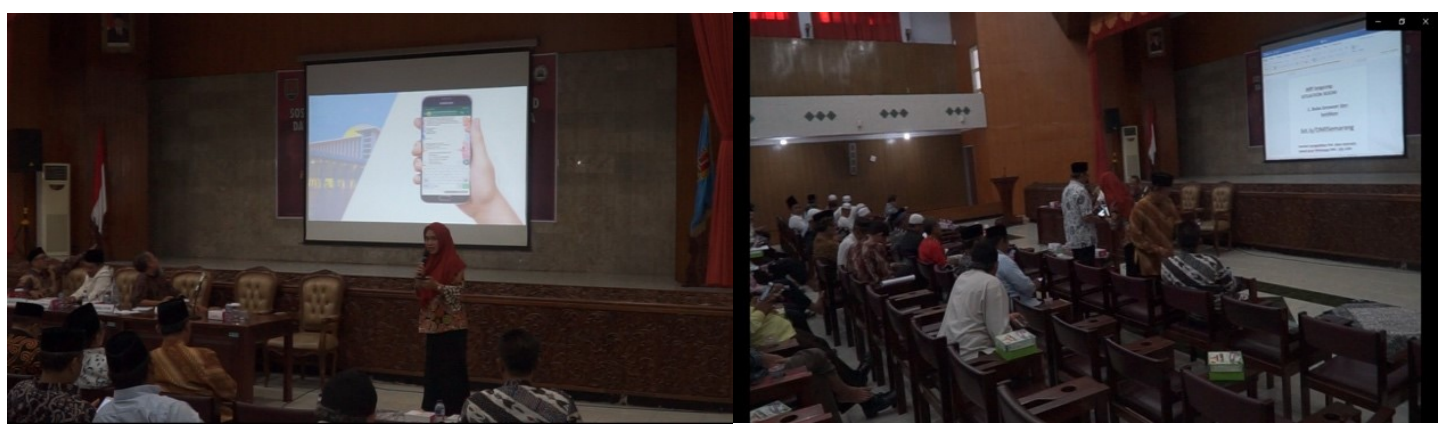

Gambar 2 Rapat Koordinasi DMI

Tahap terakhir berupa bimbingan teknis yang di berikan kepada peserta. Hasil yang di peroleh dari tahapan ini berupa peserta program pengabdian masyarakat ini memamahami dan menggunakan aplikasi DMI Kota Samarang untuk menginformasikan kegiatan pada setiap masjidnya sehingga para jamaah akan mudah menuju masjid tersebut melalui penunjuk arah yang sudah disediakan oleh aplikasi, serta peserta pengabdian masyarakat ini mendapatkan makan siang. Bukti pelaksanaan kegiatan bimbingan teknik. Berikut ini adalah kesimpulan dari target output dari program pengabdian masyarakat:

Tabel 1.Target dan Output Pengabdian Masyarakat

\begin{tabular}{|l|l|l|l|}
\hline No & Tahap & Output & Target \\
\hline 1 & $\begin{array}{l}\text { Tahap survei dan koordinasi: } \\
\text { Menganalisa masalah mitra dan } \\
\text { merencanakan agenda pelaksanaan } \\
\text { Pengabdian Masyarakat }\end{array}$ & $\begin{array}{l}\text { Melalui pelatihan pengunaan } \\
\text { aplikasi Pengurus Daerah Dewan } \\
\text { Masjid Indonesia dan Membuat } \\
\text { kesepakatan agenda pelaksanaan } \\
\text { pelatihan }\end{array}$ & $100 \%$ \\
\hline 2 & $\begin{array}{l}\text { Tahap Uji Coba: } \\
\text { Menyiapkan aplikasi dewan masjid } \\
\text { indoensia (DMI untuk pengelolaan } \\
\text { produk dan kegiatan masjid Kota } \\
\text { Semarang }\end{array}$ & $\begin{array}{l}\text { Peserta mendapatkan pengetahuan } \\
\text { berupa pelatihan dan prosedur } \\
\text { penggunaan aplikasi Dewan } \\
\text { Masjid Indoensia (DMI Kota } \\
\text { Semarang }\end{array}$ & $100 \%$ \\
\hline 3 & $\begin{array}{l}\text { Tahap Bimbingan Teknis: } \\
\text { Menyiapkan aplikasi Dewan Masjid } \\
\text { Indoensia (DMI) Kota Semarang secara } \\
\text { sempurna dan memberikan bimbingan } \\
\text { teknis kepada PD DMI Kota Semarang }\end{array}$ & $\begin{array}{l}\text { Peserta mendapatkan bimbingan } \\
\text { teknik unuk memahami dan } \\
\text { mengoperasikan aplikasi Dwan } \\
\text { Masjid Indonesia (DMI) }\end{array}$ & $100 \%$ \\
\hline
\end{tabular}

\section{KESIMPULAN}

Program pengabdian masyarakat ini bermanfaat bagi Pengurus Daerah DMI Kota Semarang, Para Takmir Masjid dan masyarakat Semarang dengan luaran berupa aplikasi Dewan Masjid Indonesia (DMI) untuk pengelolaan produk dan kegiatan masjid Kota Semarang. Selain itu melalui program pengabdian dengan mitra ini setiap peserta pelatihan dapat mengoperasikan aplikasi tersebut baik dari sisi teknis maupun adminitratif.

\section{SARAN}

Pelatihan Iptek bagi Masyarkat yang mencakup manajemen kegiatan organisasi dalam 
hal ini adalah Organisasi Pengurus Dearah Dewan Masjid Indoensia Kota Semarang. Di era industry 4.0 ini hampir semua kegiatan menggunakan Internet dan smartphone untuk mengakses informasi sehingga di perlukanya sebuah platform (aplikasi) yang mewadahi seluruh kegiatan organisasi, seingga memudahkan seluruh anggota pengurus daerah baik panitia, takmir, maupun jamaah dalam berkomunikasi satu dengan yang lain. Saran untuk kegiaatan ini berupa pelaksanaan bimbingan teknik aplikasi DMI Kota Semarang sebaiknya dilakukan di laboraturium agar semua panitia, takmir, dan jamaah dapat mengakses, menggunakan dan memahami setiap fungsi yang ada dalam aplikasi.

\section{UCAPAN TERIMA KASH}

Termakasih kami ucapkan kepada Lembaga Pengabdian Masyarakat Universitas Dian Nuswantoro yang telah memberikan fasilitas dan dukungan yang diberikan kepada kami dan PD DMI Kota Semarang, sehingga kegiatan pengabdian ini dapat berjalan dengan lancar.

\section{DAFTAR PUSTAKA}

[1] S. P. Muhammad Sholeh, "Aplikasi Mobile Pencari Masjid Dan Mushola Di Wilayah Daerah Istimewa Yogyakarta Dengan Google Maps آذر, ” Vol. 8, No. 33. P. 44, 2014.

[2] E. S. Nugroho, "Manajemen Web Untuk Mendukung Aplikasi Informasi Peta Digital Pada Smartphone Berbasis Android," Vol. 1, 2012.

[3] D. M. Isnaeni, F. Mintarsih, And F. Fahrianto, "Pencarian Masjid Terdekat," Vol. 8, No. 1, Pp. 1-10, 2015.

[4] A. Zarman Et Al., "Implementasi Algoritma Ant Colony Optimization Pada Aplikasi," Vol. I, No. 1, Pp. 6-12, 2016. 